\title{
BEGINNING OF FUNDAMENTAL REFORM OF THE STOCK MARKET IN THE REPUBLIC OF UZBEKISTAN
}

\author{
Tashkent Financial Institute, Department of "Economics" Dr. Rano Mardanova, \\ Tashkent State Agrarian University, Department of "Accounting" senior teacher Olim Azizov, \\ Tashkent Financial Institute, Department of "Economics" Dr. Xurshid Asatullayev \\ Tashkent, Uzbekistan
}

DOI: https://doi.org/10.31435/rsglobal_ijite/30112019/6794

\section{ARTICLE INFO}

Received 16 September 2019

Accepted 11 November 2019

Published 30 November 2019

\section{KEYWORDS}

Financial market, structure of financial market, segments of financial market, financiallegal policy, stock market, bond market. \begin{abstract}
The article studies the financial market in the context of the modern approach to the development of the secondary market in Uzbekistan. The author explores the main problems in the development of the secondary market, and also offers a new practical approach to the development of methods to eliminate existing problems. The achieved scientific results allow us to formulate conceptual approaches to the study of the financial market as an object of state regulation.
\end{abstract}

Citation: Rano Mardanova, Olim Azizov, Xurshid Asatullayev. (2019) Beginning of Fundamental Reform of the Stock Market in the Republic of Uzbekistan. International Journal of Innovative Technologies in Economy. 6(26). doi: 10.31435/rsglobal_ijite/30112019/6794

Copyright: (C) 2019 Rano Mardanova, Olim Azizov, Xurshid Asatullayev. This is an open-access article distributed under the terms of the Creative Commons Attribution License (CC BY). The use, distribution or reproduction in other forums is permitted, provided the original author(s) or licensor are credited and that the original publication in this journal is cited, in accordance with accepted academic practice. No use, distribution or reproduction is permitted which does not comply with these terms.

Introduction. The beginning of this year was marked by an event that the last two decades have been eagerly awaiting for all participants in the domestic stock market, and especially professional ones. Finally, the authorized state body in the field of regulation of the stock market got out of the subordination of the state administration body that exercises the functions of managing state assets, ensuring antitrust regulation, and became an independent Agency independent of it.

In accordance with the Decree of the President of the Republic of Uzbekistan Sh. Mirziyayev "On measures to radically improve the system of managing state assets, antitrust regulation of the capital market", the Agency for Management of State Assets of the Republic of Uzbekistan, the Antimonopoly Committee of the Republic of Uzbekistan and the Agency for the Development of the Capital Market were created with tasks, functions and powers in relation to the regulation of the securities market, including the organizers of securities trading, the Central Securities Depository and development of corporate governance. [Electronic resource]. URL: https:// finance.uz/ (accessed: 23/03/2019).

Everyone knows that the securities market plays a huge role in the economies of countries and in the world as a whole.

Existing mechanisms and instruments of the stock market, the national economies of developed countries attract a significant part of financial resources for their development. That is why the advanced, developed countries of the world, such as the USA, Germany, Japan and others, have well-developed and developed stock market systems that allow them to attract temporarily free cash and other funds of the population, enterprises, organizations and the state itself and direct them to finance the development of their national economies. Uzbekistan is now at a turning point in new reforms, when the stock market will begin to fulfill its most important function - the function of mobilizing temporarily free funds of the population, enterprises, corporations and the state itself, and channeling them to finance the development of various sectors of the economy. In the modern world, the reality is that securities are no longer just 
fictitious capital, and if their market is properly organized, they can serve as the most powerful financial lever that can bring the economy to a new, much higher level of development. In Uzbekistan, since independence, the main attention as a source of financing the economy has been given to a bank loan. It was banks, as institutions for raising funds from the population and enterprises and organizations, as well as the state, on a borrowed basis, that made huge investments in the real sector of the economy. The banks concentrated significant financial resources and qualified human resources. Over the years of independence, the state has provided all kinds of comprehensive support to the banking sector. Banks received huge funds and preferences from the state.

Material and methods. In 1994, the Republican Stock Exchange was established. From 1996 to 2011. The market for government securities (government current liabilities, bonds of the Central Bank) received certain development. But the stock market was mainly based on the transformation of state enterprises into joint stock companies, i.e. on privatization [2]. The issue of shares during large-scale privatization, as a result of which about five thousand state-owned enterprises turned into joint-stock companies, did not lead to the involvement of new financial resources in the turnover of enterprises and was not associated with investments, but basically meant only a change of their owner - state to private.

Theory/calculation. According to the authorized state body for regulating the securities market, over the entire period of development of the securities market in the country, the number of issued shares amounted to 6.3 trillion for a total amount at face value of 59.4 trillion Sums. As of October 1, 2019, the total amount of shares on the country's stock market reaches 25 trillion sгms, and in relation to the country's GDP this indicator does not reach 6 percent. Approximately this indicator reaches $188 \%$ in Singapore, $112 \%$ in Malaysia, and 34\% of GDP in Russia. For the previous 2018, entries in 155 share issues worth 13.4 trillion were made in the Unified State Register of Issues of Securities sums) [9]. The number of shares issued in 2018 amounted to 1.98 trillion units, the total turnover of the stock market and corporate bonds amounted to 10.71 trillion sums, up 11.53 trillion sums or 2.07 times less than the same period in 2017. [Electronic resource]. URL: http://davaktiv.uz/uz/(accessed: 07/12/2019).

In $2018,14,045$ deals worth 815.04 billion sums were concluded on the organized market, including 14,039 transactions with shares for 713.71 billion sums and 6 transactions with corporate bonds for 101.3 billion sums. The volume of transactions with shares and corporate bonds on the RSE "Tashkent" amounted to 687.88 billion sums (13,751 transactions), and on ESVT "Elsis-Savdo" 127.16 billion sums (294 transactions) [8].

Results. However, the mechanism for issuing securities and their implementation in the stock market is not used efficiently. This year bonds realized only by commercial banks through currency exchange. The number of professional participants is less than 100.Sootvetstvuyuschimi authorities planned development of the stock market in the country's development strategy 2020-2025. It is planned to increase the share of securities in free circulation in relation to GDP to 10-15 percent of the end of 2025 (today it is 0.3\%) [8]. This area is regulated by about 100 legal acts and many restrictions have been established. For example, banks are prohibited from acquiring shares in other business entities. There is also a restriction on the purchase of government bonds by citizens. Currently, the state owns 85 percent of the shares of 605 joint-stock companies, of which only 5 percent are traded on the stock market.

Today there are 300 specialists who have a certificate of qualification [Electronic resource]. URL: https:// finance.uz/ (accessed: 23/03/2019).

Without the development of the securities market, we cannot say that we switched to a market economy, and without significant privatization, this market cannot develop.

To develop the stock market, foreign exchanges, brokers, banks and insurance organizations should be involved in the domestic market.

Discussion. The assets of the banking sector are 264.5 trillion sums or more than 55 percent of GDP. Also high dollarization (in loans issued, it is 56.9\%). The capital market development agency registered 21.7 trillion sums of securities this year, an increase of $62 \%$ compared to 2018 . The number of appeals is examined -500 , of which violations on non-payment of dividends were revealed - 200 and the payment of dividends for 7.2 billion sums were ensured. [Electronic resource]. URL: https:// finance.uz/ (accessed: 12/11/2019).

During 2018, the Central Securities Depository and investment intermediaries (acting as depositaries since 2015) registered 5,743 transactions with shares and corporate bonds worth 9.89 trillion sums. The total turnover of the secondary market for stocks and corporate bonds amounted to 
1,704.4 billion sums, including: in the organized market - 487.96 billion sums (10,356 transactions); in the unorganized market - 1216.43 billion sums (4 975 transactions). [Electronic resource]. URL: http://davaktiv.uz/uz/(accessed: 07/12/2019).

In the context of industries, based on the volume of transactions, the highest turnover ratio (the ratio of trading volume to the total authorized capital of the industry JSC) in the secondary market is observed for shares of enterprises included in the structure of the Uzfarmsanoat Agency (74.8\%), business entities created with the participation of local government bodies $(41.81 \%)$, Uzozikovkatholding JSC (34.6\%), the Ministry of Water Economy (31.5\%), the National Television and Radio Company of Uzbekistan (31\%), the Uzbekkino National Agency (24.5\%), JSC "Uzagrotechsanoathholding" (13.2\%) [Electronic resource]. URL: https://cmda.gov.uz/ (accessed: 27/11/2019).

In general, enterprises of all sectors include $2.7 \%$. The volume of transactions with shares in the secondary market last year with the participation of individuals amounted to 734.73 billion sums or $45.38 \%$ of the total volume of transactions in the secondary market. The number of valid licenses for professional activities in the securities market amounted to 138 units, in particular 16 were issued in 2018, 35 were reissued, and 8 licenses were terminated [8]. The number of professional participants in the securities market, in connection with the combination of professional activities in the stock market by individual organizations, is much less - about 80 . The total number of valid qualification certificates of specialists in the securities market amounted to 325 units, including 79 - I category and 246 - II category [Electronic resource]. URL: https:// finance.uz/ (accessed: 04/08/2019).

During 2018, a total of 87 qualification certificates were issued. To revitalize the national stock market and increase its investment potential, cardinal decisions are needed [Electronic resource]. URL: https://cmda.gov.uz/ (accessed: 15/10/2019).

In 1996, a course was taken to mobilize free cash of the population and direct them to finance sectors of the national economy through the creation of investment and privatization funds. In Uzbekistan there were created more than 80 units and about the same number of management companies. In order to increase the efficiency and effectiveness of the adoption of regulations in the field of the securities market, it is necessary to constantly implement the principle of planning the development of the stock market by adopting programs for 2-year or 3-year periods.

It is advisable to develop a single document of a strategic nature - the Stock Market Code, which would combine all the laws being developed and adopted and by-laws into one document.

A well-balanced concept for the development of the national securities market is also needed, which is a guide for the long term for issuers, investors, professional participants, as well as for state regulatory bodies of the stock market). [Electronic resource] URL: http://davaktiv.uz/uz/(accessed: 07/12/2019).

In foreign financial markets, there is competition between the securities market and the bank loan market, which is the engine for the development of financial markets. Internal competition in the financial markets forces banks to lower interest rates on loans, establish more flexible conditions for issuing loans, and issuers of securities to issue them so that investors feel the benefits of investing in securities rather than banks. In Uzbekistan, such competition is practically absent. It is enough to say that only joint-stock companies have the right to raise funds for technical and technological reequipment through the issuance of securities in the republic, of which as of October 1, 2019 there were 605 units in the republic [8]. The dominant, monopoly position in the financial markets is occupied by banks. In this regard, it is time to develop a special program to increase the competitiveness of the securities market of Uzbekistan, aimed at creating such a mechanism for its functioning that would allow attracting funds to finance enterprises not only through a bank loan, but also through the issuance of securities. The preparation of such a program is very relevant in connection with the adoption at the beginning of 2012 of the Law of the Republic of Uzbekistan "On Competition", the effect of which now extends not only to commodity markets, but also to financial markets [8]. Therefore, the issue of demonopolizing the credit market as part of the financial market should be the subject of close attention of the newly created Agency for Antimonopoly Policy, whose predecessor until recently had practically not paid attention to the monopolistic position of banks in the financial markets. [Electronic resource]. URL: https:// finance.uz/ (accessed: 27/03/2019).

In order to revive the secondary market for corporate equity securities, it is necessary to drastically reduce the state's share in the authorized capital of joint-stock companies transferred by the state to the management of integrated corporate structures, and introduce a fundamentally new effective operating system for disclosing information by issuers. 
Conclusions. For strategically important and well-known privatized enterprises, whose shares can claim good liquidity, but are not put up on the market, it is advisable to define small blocks of shares in relation to the total number (up to $15 \%$ of the issue amount) for their free circulation on the stock and OTC valuable markets papers. Allocation of such a package for free sale on the market would not affect the sale of the enterprise to a strategic investor, since the latter, in order to exercise complete control over the enterprise, in most cases it is enough to own a package of $50 \%+1$ share (of voting securities) [8]. In this case, it would be advisable to consider the issue of increasing the number of joint-stock companies created on the basis of state ownership, whose shares could be offered to a wide range of investors and, above all, the population. An increase in the share of the secondary market in the total turnover of the stock market may result from the introduction of a "golden share" in joint-stock companies during the privatization, which are of priority importance for the country's economy instead of maintaining a state share in the authorized capital. At present, in order to maintain the right of veto on certain decisions of strategic management bodies of joint stock companies, the state retains a package of more than $50 \%$ of the shares of such companies, which is immobilized. The sale of state-owned shares in private ownership with the preservation of the "golden share" of large strategic enterprises by the state would allow maintaining state control over the activities of such enterprises, replenishing the revenue part of the state budget with significant funds, and most importantly - to withdraw the largest blocks of shares from the state of immobility, which are currently the main factor restraining the development of the secondary share market). [Electronic resource]. URL: http://davaktiv.uz/uz/(accessed: 07/12/2019).

Currently, there is a serious hypertrophy of the stock market on a regional scale, expressed in the fact that the overwhelming majority of transactions with shares are in Tashkent. In particular, in 2018 , the largest activity in the secondary market in terms of volumes was recorded for shares of issuers located in Tashkent city (87.2\% of the total) [8]. The development of regional (local) markets of the country has a sluggish character, in the regions there is no necessary special market infrastructure (professional participants in the securities market). In some, even large areas; there are no professional participants in the securities market, carrying out the most important types of professional activity on it. To ensure effective disclosure of information, it is necessary to radically change the approach to organizing informing investors, creating a system that operates on the principle: "not the investor is looking for information, but the information finds the investor." In order to simplify the perception of information by investors on the website of the RSE "Tashkent", information on stock quotes should be provided in a short format in accordance with generally accepted international practice, by analogy with the publication of quotations in foreign publications.

In order to interest entrepreneurs in working in the stock market, it is advisable to create economic interest for market participants. In particular, it is advisable to exempt from taxes for a period of five years income received in the form of dividends on shares and interest on corporate bonds, income derived from the circulation of securities. Given that professional activities in the securities market are related to servicing, income from professional activities in the securities market should be exempt from taxes. The financial sector of Uzbekistan is one of the fastest growing in the country's economy. However, the development of the money and credit markets, the securities market, the performance of a significant number of operations in these markets, the growth of financial services and, in particular, consumer lending against the background of financial illiteracy and citizens' lack of understanding of their rights and obligations are of concern to both the state and the financial sector itself. Until now, most of the population is distrustful and skepticism of the financial sector and especially the securities market. The insufficient level of financial literacy of the population in Uzbekistan is expressed in the inability of citizens to build long-term financial plans, make effective savings, choose financial instruments, improve their quality of life, properly assess risks, and take responsibility for their financial well-being and future. The lack of financial literacy of the population is a deterrent to the development of the financial market and the economy as a whole. To increase the level of financial literacy of the population, it is advisable to develop a special program, the purpose of which should be to increase the level of knowledge of the population about the country's financial system, functioning financial instruments, skills to use modern payment products and improve the welfare of citizens of the Republic of Uzbekistan.

The significance of the program is determined by the fact that it should contribute both to the development of the personal financial culture of the citizen of the Republic of Uzbekistan, and to the improvement of the economic situation in the country as a whole. 
It is necessary to abolish the long-obsolete legal norms, according to which transactions in the secondary market should be registered exclusively by bidders. In other countries, such a rule is not practiced. Currently, it is in connection with the presence of this norm in the legislation of Uzbekistan, after the conclusion of a transaction based on the results of competitive bidding, as well as a result of direct negotiations, even if there are appropriate protocols that determine the seller and buyer of securities, their quantity and price ( there are essential conditions of the transaction) the participants in the transaction are forced to take an additional action - to register the already "de facto" transaction on the stock exchange.

Securities markets of many countries are formed largely due to the issuance and circulation of bonds. In Uzbekistan, the bond market is virtually absent. [Electronic resource]. URL: https://cmda.gov.uz/ (accessed: 15/10/2019).

More than 162 thousand limited liability companies and 72 thousand private enterprises, including many large and financially stable enterprises with a positive credit history, do not have the opportunity to develop their activities through the issuance of securities. To eliminate the one-sided structure of the securities market (stocks occupy the overwhelming share in the total market turnover), to increase the competitiveness of the stock market in the financial services market, a number of measures are proposed aimed at creating an enterprise bond market. [Electronic resource]. URL: https://cmda.gov.uz/ (accessed: 14/11/2019).

To do this, it is necessary to revise the approaches regarding the conditions for issuing bonds by enterprises of the republic, providing for the following points:

- consider corporate bonds as one of the main types of securities, and corporate, infrastructural, and commercial bonds as their varieties. At the same time, to allow the issuance of enterprise bonds to state enterprises, joint-stock companies, limited liability companies, private enterprises;

- at the legislative level, determine the types of bonds of enterprises that can be issued, clearly describing the signs, conditions and mechanisms of issue, circulation and redemption, the distinctive features of each type;

- initiate the issuance of exchange-traded bonds by enterprises whose shares have successfully passed the listing procedure, are included in the exchange quotation list of the Republican Stock Exchange with significant liberalization of the conditions for their registration with the authorized state body for regulating the securities market.

To raise funds at the regional level, it is also necessary to allow the issuance of bonds to local authorities - municipal bonds.

In the conceptual documents on the development of the securities market for the medium term, it is advisable to provide for the development and implementation of the national innovative software product "Unified software and hardware complex of the securities market of Uzbekistan", which provides a multifunctional mechanism for accounting and storage of securities, conducting trading in securities, and clearing operations in the market Securities, which should be developed by domestic programmers, responding exclusively to the national the interests of the Republic of Uzbekistan.

The capital market development agency offers targets by 2025 :

- The free float of securities is 10 percent of GDP or 60 trillion sums - 20 trillion sums of shares, 20 trillion government bonds and 20 trillion sums of treasury bonds [8];

- The market capitalization of shares should be increased to 80 trillion sums or $13.3 \%$ of GDP or more than 2 times higher than in 2019.

Offered:

Central Securities Depository:

- Formation of a single national depository for the stock and foreign exchange markets;

-Settlement transactions on equity securities by opening a correspondent account with the Central Bank.

Stock Exchange "Tashkent":

- Improvement of the rules;

- Introduction of hedging instruments.

Capital Market Development Agency:

- Addition and alternative to the banking sector;

- Increase in market liquidity;

- diversified financing instruments.

The implementation of the proposals and recommendations formulated above will further enhance the investment potential of the securities market and develop the economy. 


\section{REFERENCES}

1. Alekhine, B.I. Government Securities Market: Textbook / B.I. Alekhine. - M.: Master, INFRA-M, 2011.- 192.

2. Alekhine, B.I. Securities Market: Textbook / B.I. Alekhine. - M.: UNITY, 2006. - 461 c.

3. Aliev, A.R. Securities Market in Russia. Tutorial. Grif UMTS "Professional textbook" / A.R. Aliev - M.: UNITY, 2013. - 199 p.

4. Aliev, A.R. Securities Market in Russia. Tutorial. / A.R. Aliev - M.: UNITY, 2013. - 199 p.

5. Arshavsky, A.Yu. Securities Market: Textbook for Bachelors / N.I. Berzon, D.M. Kasatkin, A.Yu. Arshavsky. - M.: Yurayt, 2013.- 537 p.

6. Batyaeva, T.A. Securities Market: Textbook / T.A. Batyaeva I.I. Joiners. - M.: INFRA-M, 2010.- 304 p.

7. Beloglazova, G.N. Securities market: tools and mechanisms of functioning. Textbook for universities / G.N. Beloglazova, L.P. Krolivetskaya. - M.: KnoRus, 2010.- 272 p.

8. Butikov, Igor: Securities market in Uzbekistan, new horizons. [Electronic resource]. URL: https:// finance.uz/ (accessed: 27/03/2019).

9. Krinichinsky, K.V. Stocks and bods market. 2nd ed., Trans. and add. / K.V. Krinichinsky. - M.: DiS, 2010.- 608 p.

10. Kuznetsov, B.T. Securities Market: Textbook for university students enrolled in the specialty "Finance and Credit" / B.T. Kuznetsov. - M.: UNITY-DANA, 2013. - 288 p.

11. Kuznetsov, B.T. Stocks and bods market. Tutorial. Vulture UMTS "Professional textbook". / B.T. Kuznetsov. - M.: UNITY, 2013. - 288 c.

12. Kuznetsov, B.T. Stocks and bods market. Tutorial. / B.T. Kuznetsov. - M.: UNITY, 2013. - 288 c.

13. Lyalin, V.A. Securities Market in Questions and Answers. Uch.pos. - M.: Prospect, 2015. / V.A. Lyalin, P.V. Vorobiev, I.A. Darushin. - M.: Prospect, 2015. 336 p.

14. Lyalin, V.A. Stocks and bods market. The textbook. 2nd ed., Trans. and add. / V.A. Lyalin, P.V. Vorobiev. - M.: Prospect, 2015.- 400 p.

15. Lyalin, V.A. Stocks and bods market. Textbook. 2nd ed. / V.A. Lyalin, P.V. Vorobiev. - M.: Prospect, 2016. - 400 p.

16. Markova, O.M. Laboratory workshop on the disciplines "Securities Market" and "Banks and non-bank credit organizations and their operations" / L.T. Litvinenko, O.M. Markova, N.N. Martynenko. - M.: University textbook, SIC INFRA-M, 2013. - 233 p.

17. Sheshukova, T.G. Securities Market: Theory and Practice. Textbook / T.G. Sheshukova. - M.: Finance and Statistics, 2008. - 752 c.

18. [Electronic resource] URL: https://finance.uz/index.php/ru/fuz-menu-economy-ru/4502-igor-butikovrynok-tsennykh-bumag-uzbekistana-novye-gorizonty

19. [Electronic resource] URL: https://cmda.gov.uz/uz/

20. [Electronic resource] URL: http://davaktiv.uz/uz/ 